\title{
Article \\ Study on Oxygen Evolution Reaction Performance of Jarosite/C Composites
}

\author{
Junxue Chen ${ }^{\dagger}$, Sijia $\mathrm{Li}^{\dagger}{ }^{\dagger}$, Zizheng Qu, Zhonglin Li, Ding Wang, Jialong Shen * and Yibing Li *
}

check for updates

Citation: Chen, J.; Li, S.; Qu, Z.; Li, Z.; Wang, D.; Shen, J.; Li, Y. Study on

Oxygen Evolution Reaction

Performance of Jarosite/C

Composites. Materials 2022, 15, 668

https://doi.org/10.3390/

ma15020668

Academic Editor: Marc Cretin

Received: 30 November 2021

Accepted: 11 January 2022

Published: 17 January 2022

Publisher's Note: MDPI stays neutral with regard to jurisdictional claims in published maps and institutional affiliations.

Copyright: (C) 2022 by the authors. Licensee MDPI, Basel, Switzerland. This article is an open access article distributed under the terms and conditions of the Creative Commons Attribution (CC BY) license (https:// creativecommons.org/licenses/by/ $4.0 /)$.
Department of Materials Science and Engineering, Guilin University of Technology, Guilin 541000, China; cchenjunxue@gmail.com (J.C.); lisj701023@gmail.com (S.L.); dadpro01@gmail.com (Z.Q.); dahe121133@gmail.com (Z.L.); dingnvhuang@gmail.com (D.W.)

* Correspondence: Jialong.Shen@glut.edu.cn (J.S.); lybgems@glut.edu.cn (Y.L.)

+ These authors contributed equally to this work.

\begin{abstract}
In the electrolysis of water process, hydrogen is produced and the anodic oxygen evolution reaction (OER) dominates the reaction rate of the entire process. Currently, OER catalysts mostly consist of noble metal (NM) catalysts, which cannot be applied in industries due to the high price. It is of great importance to developing low-cost catalysts materials as $\mathrm{NM}$ materials substitution. In this work, jarosite $\left(\mathrm{AFe}_{3}\left(\mathrm{SO}_{4}\right)_{2}(\mathrm{OH})_{6}, \mathrm{~A}=\mathrm{K}^{+}, \mathrm{Na}^{+}, \mathrm{NH}^{4+}, \mathrm{H}_{3} \mathrm{O}^{+}\right)$was synthesized by a onestep method, and its OER catalytic performance was studied using catalytic slurry (the weight ratios of jarosite and conductive carbon black are 2:1, 1:1 and 1:2). Microstructures and functional groups of synthesized material were analyzed using XRD, SEM, FI-IR, etc. The OER catalytic performance of $\left(\mathrm{NH}_{4}\right) \mathrm{Fe}_{3}\left(\mathrm{SO}_{4}\right)_{2}(\mathrm{OH})_{6}$ / conductive carbon black were examined by LSV, Tafel, EIS, ECSA, etc. The study found that the OER has the best catalytic performance when the weight ratio of $\left(\mathrm{NH}_{4}\right) \mathrm{Fe}_{3}\left(\mathrm{SO}_{4}\right)_{2}(\mathrm{OH})_{6}$ to conductive carbon black is 2:1. It requires only $376 \mathrm{mV}$ overpotential to generate current densities of $10 \mathrm{~mA} \mathrm{~cm}^{-2}$ with a small Tafel slope $\left(82.42 \mathrm{mV} \mathrm{dec}^{-1}\right)$ and large $\mathrm{C}_{\mathrm{dl}}$ value $\left(26.17 \mathrm{mF} \mathrm{cm}^{-2}\right)$.
\end{abstract}

Keywords: jarosite; ammoniojarosite; electrocatalyst; oxygen evolution reaction; stability

\section{Introduction}

With the increasingly negative impact of fossil fuels on the environment, it is with a huge demand that modern science and technology need to pursue clean and sustainable energy [1,2]. Hydrogen production by water splitting, as a technology for producing clean energy, has caused extensive researches [3,4]. The electrochemical water splitting process includes the oxygen evolution reaction (OER) at the anode and the hydrogen evolution reaction (HER) at the cathode. The HER reaction is a two-electron transfer process, while OER is a four-electron transfer process, whose higher energy barrier dominates the rate of the cathodic hydrogen production [5]. Therefore, the development and research of costeffective OER catalysts with high activity and long-periodic cycle stability is a primary task.

Noble-metal-based materials, including $\mathrm{IrO}_{2}$ and $\mathrm{RuO}_{2}$, are state-of-the-art OER electrocatalysts because of their high electrocatalytic OER activity both in alkaline and acidic solutions [6-8]. However, the large-scale application of $\mathrm{IrO}_{2}$ and $\mathrm{RuO}_{2}$ in OER is severely limited not only by the high cost but also by the scarcity of Ir and Ru [9]. Thus far, considerable research efforts have been devoted to the exploration of low-cost and highly active noble-metal-free catalysts to replace expensive and scarce precious catalysts [10-12]. Especially for transition metal Fe-based materials, including oxides/hydroxides [13-15], chalcogenides [16], phosphides [16,17], and nitrides [18], which have been investigated extensively as promising candidates for the OER.

Compared with these compounds, Fe-based polyanionic compounds [1-4], such as jarosite, are an earth-abundant natural mineral that belongs to the alunite supergroup with the formula $\mathrm{AFe}_{3}\left(\mathrm{SO}_{4}\right)_{2}(\mathrm{OH})_{6}$, where A represents different monovalent cations, such as 
$\mathrm{K}^{+}, \mathrm{Na}^{+}, \mathrm{NH}_{4}{ }^{+}$, and $\mathrm{H}_{3} \mathrm{O}^{+}$. At present, jarosite has been extensively studied by the acid leach mining industry due to the precipitation of jarosite in acidic media-a crucial step that allows for the physical separation of $\mathrm{Fe}^{3+}$ and other cations from the leach solution [19-23]. As a result, these refining plants produce large amounts of environmentally hazardous jarosite wastes that currently provide no commercial value. Fortunately, several researchers have explored the use of jarosite as a cathode in the lithium and sodium-ion battery [24-26]. According to our best efforts, there is no research on jarosite in OER so far. Therefore, exploring and tapping the potential of these environmentally harmful jarosite wastes in the field of OER is an attractive strategy to provide economic advantages for jarosite.

In this work, the design of applying jarosite to OER catalytic material is proposed. A simple one-step method was used to synthesize four various types of jarosite materials $\left(\left(\mathrm{NaFe}_{3}\left(\mathrm{SO}_{4}\right)_{2}(\mathrm{OH})_{6}\right), \mathrm{KFe}_{3}\left(\mathrm{SO}_{4}\right)_{2}(\mathrm{OH})_{6}\right),\left(\mathrm{NH}_{4}\right) \mathrm{Fe}_{3}\left(\mathrm{SO}_{4}\right)_{2}(\mathrm{OH})_{6}$, and $\left.\left(\left(\mathrm{H}_{3} \mathrm{O}\right) \mathrm{Fe}_{3}\left(\mathrm{SO}_{4}\right)_{2}(\mathrm{OH})_{6}\right)\right)$. We explored the OER performance of these four catalysts under acidic, neutral and alkaline conditions. The electrochemical test results suggest that $\left(\mathrm{NH}_{4}\right) \mathrm{Fe}_{3}\left(\mathrm{SO}_{4}\right)_{2}(\mathrm{OH})_{6}$ shows the best OER activity among the four catalysts. When the weight ratio of $\left(\mathrm{NH}_{4}\right) \mathrm{Fe}_{3}\left(\mathrm{SO}_{4}\right)_{2}(\mathrm{OH})_{6}$ to conductive carbon black is 2:1, the overpotential of $\left(\mathrm{NH}_{4}\right) \mathrm{Fe}_{3}\left(\mathrm{SO}_{4}\right)_{2}(\mathrm{OH})_{6}$ is $376 \mathrm{mV}$ at a current density of $10 \mathrm{~mA} \mathrm{~cm}^{-2}$ in alkaline conditions. Although this performance is not comparable to that of precious metals $\left(\mathrm{IrO}_{2}\right)$, there is a lot of room to improve the performance, which is our future research task. In short, exploring the application of jarosite waste in OER can not only protect the environment but also improve its economic value.

\section{Experimental Section}

\subsection{Materials}

$\mathrm{Fe}\left(\mathrm{SO}_{4}\right) \cdot 7 \mathrm{H}_{2} \mathrm{O}(99.0 \sim 101.0 \%), \mathrm{K}_{2} \mathrm{CO}_{3}(99 \%), \mathrm{Na}_{2} \mathrm{CO}_{3}(99.8 \%),\left(\mathrm{NH}_{4}\right)_{2} \mathrm{SO}_{4}(98.0 \%)$, $\mathrm{NH}_{3} \cdot 7 \mathrm{H}_{2} \mathrm{O}(25.0 \sim 28.0 \%)$ and $\mathrm{C}_{2} \mathrm{H}_{5} \mathrm{OH}(99.7 \%)$ were purchased from Guangxi Dragon Technology Company (Guangxi, China). Conductive carbon black (Ketjenblack) and Nafion solution (5 wt \%) were purchased from Suzhou Yilongsheng Energy Technology Co., Ltd. (Suzhou, China) All chemicals used were of analytical grade and there was no need to further purification.

\subsection{Preparation of $(\mathrm{A}) \mathrm{Fe}_{3}\left(\mathrm{SO}_{4}\right)_{2}(\mathrm{OH})_{6},\left(\mathrm{~A}=\mathrm{K}^{+}, \mathrm{Na}^{+}\right.$and $\left.\mathrm{NH}_{4}{ }^{+}\right)$}

$\mathrm{FeSO}_{4}$ and $\left(\mathrm{NH}_{4}\right)_{2} \mathrm{SO}_{4}$ were dissolved in $250 \mathrm{~mL}$ and $100 \mathrm{~mL}$ of deionized water to form solution A (0.02 $\left.\mathrm{M} \mathrm{FeSO}_{4}\right)$ and solution $\mathrm{B}\left(0.5 \mathrm{M}\left(\mathrm{NH}_{4}\right)_{2} \mathrm{SO}_{4}\right)$, respectively. Dilute $\mathrm{H}_{2} \mathrm{O}_{2}$ solution was added dropwise to solution $\mathrm{A}$ to oxidize $\mathrm{Fe}^{2+}$ to $\mathrm{Fe}^{3+}$ and then solution $\mathrm{B}$ was injected into the above solution with a water bath at a constant temperature of $95^{\circ} \mathrm{C}$ and stirred magnetically for $3 \mathrm{~h}$, meanwhile, the $\mathrm{pH}$ value of the mixed solution was maintained throughout at 1.5-2.0 with $1 \mathrm{M}$ ammonia solution. Finally, the yellow precipitate $\left(\mathrm{NH}_{4}\right) \mathrm{Fe}_{3}\left(\mathrm{SO}_{4}\right)_{2}(\mathrm{OH})_{6}$ catalyst was collected, washed with deionized water and then dried in a vacuum at $80^{\circ} \mathrm{C}$. The main synthesis procedure for $\mathrm{Na} / \mathrm{KFe}_{3}\left(\mathrm{SO}_{4}\right)_{2}(\mathrm{OH})_{6}$ is similar to that for $\left(\mathrm{NH}_{4}\right) \mathrm{Fe}_{3}\left(\mathrm{SO}_{4}\right)_{2}(\mathrm{OH})_{6}$, corresponding to the use of $0.5 \mathrm{M} \mathrm{Na}_{2} \mathrm{CO}_{3}$ and $\mathrm{K}_{2} \mathrm{CO}_{3}$ instead of $0.5 \mathrm{M}\left(\mathrm{NH}_{4}\right)_{2} \mathrm{SO}_{4}$ solution and the replacement of the $\mathrm{pH}$ adjuster with $1 \mathrm{M} \mathrm{Na}_{2} \mathrm{CO}_{3}$ and $\mathrm{K}_{2} \mathrm{CO}_{3}$ solution, respectively.

\subsection{Preparation of $\left(\mathrm{H}_{2} \mathrm{O}\right) \mathrm{Fe}_{3}\left(\mathrm{SO}_{4}\right)_{2}(\mathrm{OH})_{6}$}

A certain amount of $\mathrm{FeSO}_{4}$ was dispersed in $70 \mathrm{~mL}$ of deionized water, with stirring at $95^{\circ} \mathrm{C} . \mathrm{H}_{2} \mathrm{O}_{2}$ was used to oxidize $\mathrm{Fe}^{2+}$ to $\mathrm{Fe}^{3+}$. After it was completely oxidized, the reactants were transferred to a $100 \mathrm{~mL}$ reactor at $120^{\circ} \mathrm{C}$ and kept for $12 \mathrm{~h}$. The final product was collected after filtration and washed with deionized water several times.

\subsection{Preparation of Working Electrode}

Add 10 mg NH $\mathrm{N}_{4}-\mathrm{Fe}_{3} @ \mathrm{~KB}-1\left(\left(\mathrm{NH}_{4}\right) \mathrm{Fe}_{3}\left(\mathrm{SO}_{4}\right)_{2}(\mathrm{OH})_{6}\right.$ and conductive carbon black with a mass ratio of 2:1). These were dispersed into a mixed solvent of Nafion $(30 \mu \mathrm{L})$, anhydrous ethanol $(400 \mu \mathrm{L})$ and deionized water $(600 \mu \mathrm{L})$. Form a uniform dispersion after ultrasonic for $30 \mathrm{~min}$, then use a pipette gun to take the dispersion $(4 \mu \mathrm{L})$, add to the glassy carbon 
electrode and dry. The working electrodes of other catalytic materials are prepared by using the same method.

\subsection{Characterization}

Scanning electron microscopy (SEM, Hitachi Works, Ltd., Tokyo, Japan) was conducted on S-4800 at $5 \mathrm{kV}$ to perform microstructure analysis. The phase structure of the sample was analyzed by a X-ray powder diffractometer (XRD, X'Pert PRO, PANalytical B.V, Cu $\mathrm{K} \alpha, 40 \mathrm{kV}, 40 \mathrm{~mA}, \lambda=1.54056 \AA$, PANalytical B.V., Almelo, The Netherlands) at a scanning rate of $5^{\circ} \cdot \mathrm{min}^{-1}$. The functional groups of the samples were analyzed by Fourier transform infrared (FTIR, Thermo Nexus 407 spectrometer, White Bear Lake, MN, USA) and the laser Raman confocal microscope Raman spectrometer (Raman, Thermo Fisher Scientific DXR, thermoelectric company, $532 \mathrm{~nm}$, White Bear Lake, MN, USA). Transmission electron microscopy (TEM, JEOL, Beijing, China) images were collected on Titan G260-300 at an acceleration voltage of $200 \mathrm{kV}$. Before BET and BJH measured via Surface area and pore porosimetry analyzer NoVA 1200e (Quantachrome Instruments, Shanghai, China), all samples were degassed for $5 \mathrm{~h}$ at $100^{\circ} \mathrm{C}$.

\subsection{Electrochemical Measurements}

All electrochemical measurements were conducted on a computer-controlled CHI $760 \mathrm{E}$ electrochemical workstation with a conventional three-electrode system. The glassy carbon electrode with a diameter of $3 \mathrm{~mm}$ was used as a working electrode, $\mathrm{Ag} / \mathrm{AgCl}$ electrode and $\mathrm{Hg} / \mathrm{HgO}$ electrode were respectively used as the reference electrode for the acidic (neutral) system and alkaline system, and graphite rods were used as a counter electrode. The measurements were performed in three different electrolytes, $0.05 \mathrm{M}$ $\mathrm{H}_{2} \mathrm{SO}_{4}, 1 \mathrm{M} \mathrm{KOH}$, and $1 \mathrm{M}$ PBS. All the potentials were converted to reversible hydrogen electrode (RHE) based on the formula $\mathrm{E}_{\mathrm{RHE}}=\mathrm{E}_{\mathrm{Hg} / \mathrm{HgO}}+0.0591 \times \mathrm{pH}+0.098$ and $\mathrm{E}_{\mathrm{RHE}}=\mathrm{E}_{\mathrm{Ag} / \mathrm{AgCl}}+0.0591 \times \mathrm{pH}+0.1976$. The polarization curves were measured at $5 \mathrm{mV} \mathrm{s}^{-1}$ and iR-corrected. Tafel plots were calculated using the Tafel formula $\eta=b \log j+a$, where $j$ is the current density, $b$ is the Tafel slope, and $a$ is the intercept relative to the exchange current density. EIS measurements were conducted under a particular applied potential in the frequency range $0.1 \mathrm{~Hz}$ to $100 \mathrm{kHz}$. The electrochemically active surface area (ECSA) was estimated by the double-layer capacitance $\left(\mathrm{C}_{\mathrm{dl}}\right)$. The time-current curve was measured at a fixed voltage corresponding to $10 \mathrm{~mA} \mathrm{~cm}^{-2}$ of current density. All tests were performed at room temperature.

\section{Results and Discussion}

\subsection{Characterization of Samples}

Four various types of jarosite were synthesized, named $\mathrm{NaFe}_{3}\left(\mathrm{SO}_{4}\right)_{2}(\mathrm{OH}), \mathrm{KFe}_{3}(\mathrm{SO} 4)_{2}(\mathrm{OH})_{6}$ $\left(\mathrm{NH}_{4}\right) \mathrm{Fe}_{3}\left(\mathrm{SO}_{4}\right)_{2}(\mathrm{OH})_{6}$ and $\left(\mathrm{H}_{3} \mathrm{O}\right) \mathrm{Fe}_{3}\left(\mathrm{SO}_{4}\right)_{2}(\mathrm{OH})_{6}$, respectively. The crystal structure of various types of jarosite was firstly investigated by X-ray diffraction (XRD). As shown in Figure 1a, the diffraction pattern of the as-prepared jarosite can be indexed to the hexagonal system with a space group of $\mathrm{R} 3 \mathrm{~m}$, suggesting the successful preparation of the jarosite samples.

Figure $1 \mathrm{~b}$ shows the infrared spectrum test chart of the jarosite. The infrared absorption peaks of different jarosite appear at similar positions. The peaks appearing at $469 \mathrm{~cm}^{-1}$ and $502 \mathrm{~cm}^{-1}$ are Fe-O peaks. The corresponding peaks at $624 \mathrm{~cm}^{-1}, 1082 \mathrm{~cm}^{-1}$, and $1204 \mathrm{~cm}^{-1}$ are $\mathrm{SO}_{4}{ }^{2-}$. The broad and strong absorption peaks at $1004 \mathrm{~cm}^{-1}$ and $3416 \sim 3700 \mathrm{~cm}^{-1}$ are the stretching vibrations of $-\mathrm{OH}$ and the weaker absorption peak at $1638 \mathrm{~cm}^{-1}$ is caused by the bending vibration of $\mathrm{H}_{2} \mathrm{O}[27,28]$. A sharp peak appears at $1425 \mathrm{~cm}^{-1}$ in the infrared spectrum of $\left(\mathrm{NH}_{4}\right) \mathrm{Fe}_{3}\left(\mathrm{SO}_{4}\right)_{2}(\mathrm{OH})_{6}$, which is regarded as the absorption of the $-\mathrm{NH}_{4}$ peak. According to the findings in the report [15], transition metal hydroxides have good OER catalytic performance and the presence of hydroxyl groups in jarosite makes it possible to have OER catalytic performance. This view is confirmed in the following electrochemical performance test. 

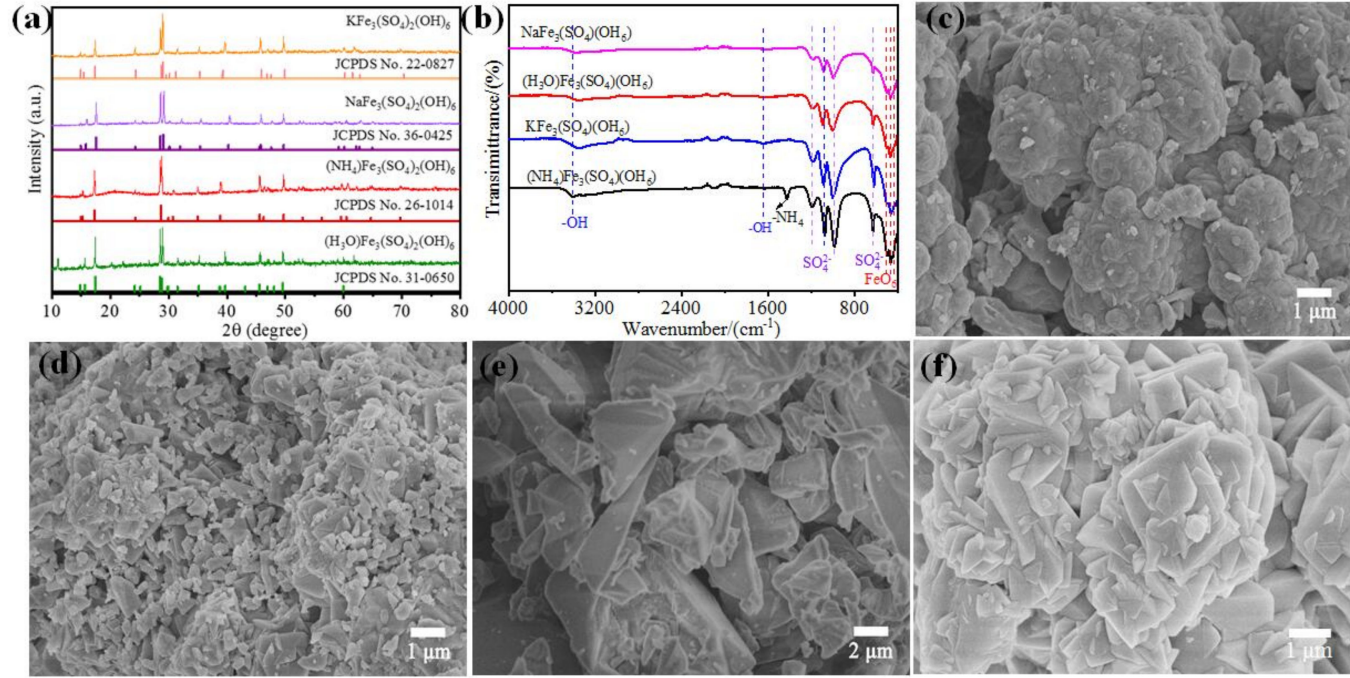

Figure 1. (a) XRD patterns and (b) FT-IR spectra of various types of jarosite. SEM images of (c) $\mathrm{KFe}_{3}\left(\mathrm{SO}_{4}\right)_{2}(\mathrm{OH})_{6},(\mathbf{d}) \mathrm{NaFe}_{3}\left(\mathrm{SO}_{4}\right)_{2}(\mathrm{OH})_{6},(\mathbf{e})\left(\mathrm{H}_{3} \mathrm{O}\right) \mathrm{Fe}_{3}\left(\mathrm{SO}_{4}\right)_{2}(\mathrm{OH})_{6}$ and $(\mathbf{f})\left(\mathrm{NH}_{4}\right) \mathrm{Fe}_{3}\left(\mathrm{SO}_{4}\right)_{2}(\mathrm{OH})_{6}$.

It can be seen from the figure that $\mathrm{KFe}_{3}\left(\mathrm{SO}_{4}\right)_{2}(\mathrm{OH})_{6}$ (Figure 1c) and $\mathrm{NaFe}_{3}\left(\mathrm{SO}_{4}\right)_{2}(\mathrm{OH})_{6}$ (Figure 1d) have similar morphologies. Both of them are densely packed. The precipitation rate of $\mathrm{KFe}_{3}\left(\mathrm{SO}_{4}\right)_{2}(\mathrm{OH})_{6}$ is fast and the sample morphology has not yet been completely formed before it settles together. In the morphology of $\mathrm{NaFe}_{3}\left(\mathrm{SO}_{4}\right)_{2}(\mathrm{OH})_{6}$, it can be observed that they are stacked together in a rhombic structure, which has not yet been completely formed. It can be seen from Figure 1e that the particle diameter is larger and the shape is irregular. $\left(\mathrm{NH}_{4}\right) \mathrm{Fe}_{3}\left(\mathrm{SO}_{4}\right)_{2}(\mathrm{OH})_{6}$ (Figure $1 \mathrm{f}$ ) is uniformly distributed in lumps of different sizes while particles do not appear to pile up, showing a larger specific surface area.

The nitrogen adsorption-desorption isotherm curves of the as-synthesized catalyst under various pressures were characterized with a Surface Area and Pore Porosimetry Analyzer NoVA 1200e., and the specific surface area and pore size distribution were calculated via Brumaire-Emmett-Teller(BET) and Barret-Joyner-Hallender (BJH) methods. As shown in Figure 2, $\left(\mathrm{NH}_{4}\right) \mathrm{Fe}_{3}\left(\mathrm{SO}_{4}\right)_{2}(\mathrm{OH})_{6}$ displays the highest BET surface areas of $6.5845 \mathrm{~m}^{2} \mathrm{~g}^{-1}$, which is higher than that of $\mathrm{KFe}_{3}\left(\mathrm{SO}_{4}\right)_{2}(\mathrm{OH})_{6}\left(4.6879 \mathrm{~m}^{2} \mathrm{~g}^{-1}\right)$, $\mathrm{NaFe}_{3}\left(\mathrm{SO}_{4}\right)_{2}(\mathrm{OH})_{6}\left(4.1587 \mathrm{~m}^{2} \mathrm{~g}^{-1}\right)$, and $\left(\mathrm{H}_{3} \mathrm{O}\right) \mathrm{Fe}_{3}\left(\mathrm{SO}_{4}\right)_{2}(\mathrm{OH})_{6}\left(2.5179 \mathrm{~m}^{2} \mathrm{~g}^{-1}\right)$. The pore size distribution curves of the four materials in Figure $2 \mathrm{~b}$ suggest the existence of a mesoporous structure $(\sim 8 \mathrm{~nm})$. The large specific surface area of the catalyst is very beneficial for the exposure of catalytic active sites for OER.
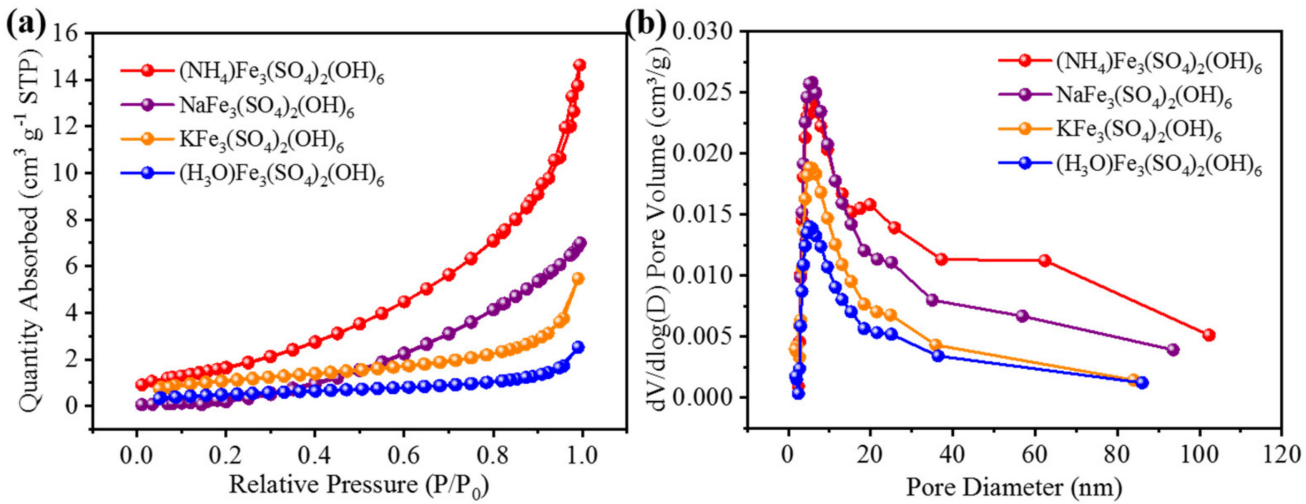

Figure 2. (a) $\mathrm{N}_{2}$ adsorption-desorption isotherm curves, (b) the corresponding pore size distribution curves. 
Transmission electron microscopy (TEM) was carried out to further identify the details of samples. Figure $3 a, b$ shows the lamellar structure of the sample. It shows some branchlike structures, which can provide more active sites. The selected-area electron-diffraction (SAED) pattern (inset of Figure 3b) of $\left(\mathrm{NH}_{4}\right) \mathrm{Fe}_{3}\left(\mathrm{SO}_{4}\right)_{2}(\mathrm{OH})_{6}$ was also recorded. It displays the weak diffraction rings, which further explained how the prepared $\left(\mathrm{NH}_{4}\right) \mathrm{Fe}_{3}\left(\mathrm{SO}_{4}\right)_{2}(\mathrm{OH})_{6}$ possesses poor crystallization form. Figure $3 \mathrm{c}$ shows the recorded high-resolution transmission electron microscopy (HRTEM) image of the $\left(\mathrm{NH}_{4}\right) \mathrm{Fe}_{3}\left(\mathrm{SO}_{4}\right)_{2}(\mathrm{OH})_{6}$. The interplanar spacing of $0.287 \mathrm{~nm}$ was indexed matching the (006) crystal plane of $\left(\mathrm{NH}_{4}\right) \mathrm{Fe}_{3}\left(\mathrm{SO}_{4}\right)_{2}(\mathrm{OH})$, which is in good agreement with the XRD spectra. Furthermore, the high-angle annular dark-field scanning-TEM (HAADF-STEM) and its corresponding mapping were employed to analyze the distribution of the elements in the $\left(\mathrm{NH}_{4}\right) \mathrm{Fe}_{3}\left(\mathrm{SO}_{4}\right)_{2}(\mathrm{OH})_{6}$ catalyst. It shows that $\mathrm{Fe}, \mathrm{N}, \mathrm{O}$, and $\mathrm{S}$ are evenly distributed across the entire nanoparticles without any noticeable segregation.

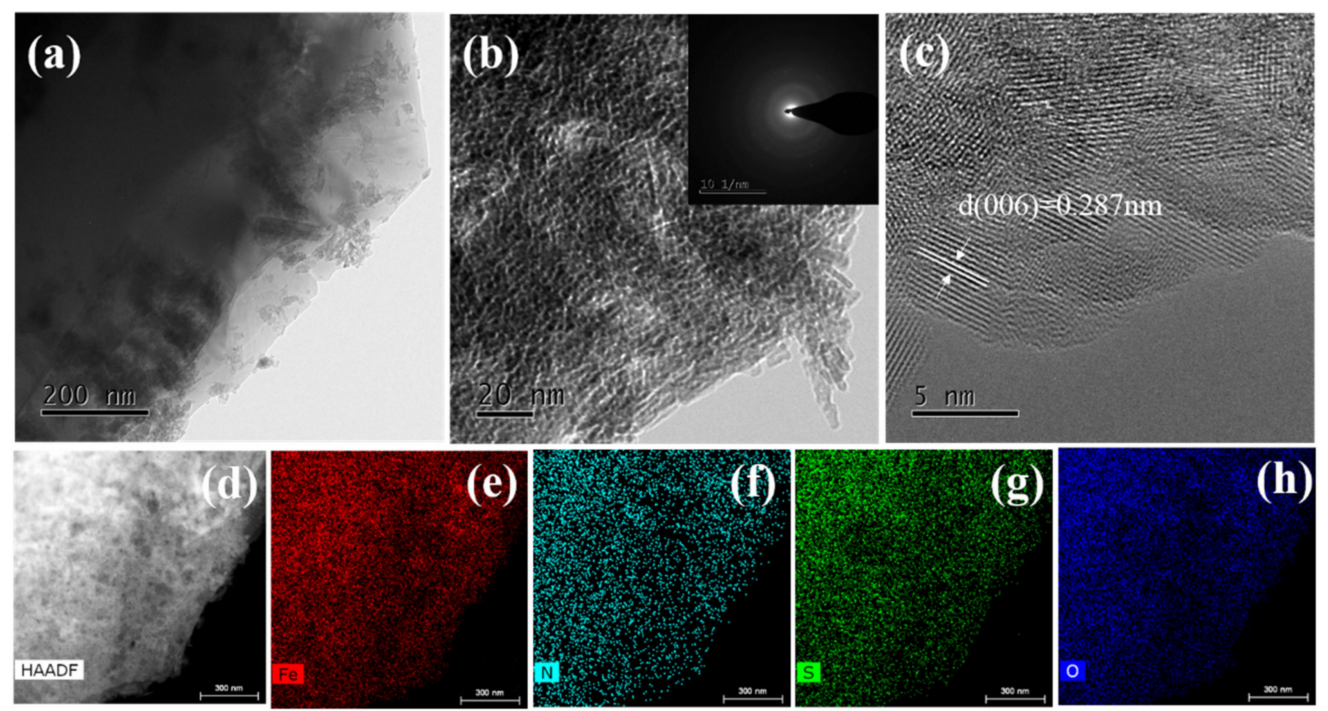

Figure 3. (a,b) TEM images (the inset shows SAED), (c) HRTEM image, and (d-h) HAADF-TEM diagrams of $\left(\mathrm{NH}_{4}\right) \mathrm{Fe}_{3}\left(\mathrm{SO}_{4}\right)_{2}(\mathrm{OH})_{6}$ and the corresponding EDS elemental mapping images.

\subsection{Electrochemical Analysis}

To increase the electronic conductivity of the jarosite, the catalyst slurry with a weight ratio of 1:1 (jarosite to conductive carbon black) was prepared and an OER polarization curve performance test was conducted. As shown in Figure $4 \mathrm{a}$, when the current density is $10 \mathrm{~mA} \mathrm{~cm}{ }^{-2}$, the overpotentials of $\mathrm{KFe}_{3}\left(\mathrm{SO}_{4}\right)_{2}(\mathrm{OH})_{6}, \mathrm{NaFe}_{3}\left(\mathrm{SO}_{4}\right)_{2}(\mathrm{OH})_{6}$, $\left(\mathrm{H}_{3} \mathrm{O}\right) \mathrm{Fe}_{3}\left(\mathrm{SO}_{4}\right)_{2}(\mathrm{OH})_{6}$, and $\left(\mathrm{NH}_{4}\right) \mathrm{Fe}_{3}\left(\mathrm{SO}_{4}\right)_{2}(\mathrm{OH})_{6}$ are $412 \mathrm{mV}, 400 \mathrm{mV}, 424 \mathrm{mV}$, and $394 \mathrm{mV}$, respectively. Meanwhile, the Tafel slope of the $\left(\mathrm{NH}_{4}\right) \mathrm{Fe}_{3}\left(\mathrm{SO}_{4}\right)_{2}(\mathrm{OH})_{6}$ is $127.31 \mathrm{mV} \mathrm{dec}^{-1}$, which is smaller than those of the $\mathrm{NaFe}_{3}\left(\mathrm{SO}_{4}\right)_{2}(\mathrm{OH})_{6}\left(135.86 \mathrm{mV} \mathrm{dec}{ }^{-1}\right), \mathrm{KFe}_{3}\left(\mathrm{SO}_{4}\right)_{2}(\mathrm{OH})_{6}$ $\left(144.81 \mathrm{mV} \mathrm{dec}^{-1}\right)$ and $\left(\mathrm{H}_{3} \mathrm{O}\right) \mathrm{Fe}_{3}\left(\mathrm{SO}_{4}\right)_{2}(\mathrm{OH})_{6}\left(148.85 \mathrm{mV} \mathrm{dec}^{-1}\right)$, which indicates that $\left(\mathrm{NH}_{4}\right) \mathrm{Fe}_{3}\left(\mathrm{SO}_{4}\right)_{2}(\mathrm{OH})_{6}$ shows an excellent OER activity among the four jarosite catalysts.

In addition, OER tests were carried out on four catalyst materials in the acidic $\left(\mathrm{pH}=1 \mathrm{H}_{2} \mathrm{SO}_{4}\right)$ and neutral $(\mathrm{pH}=7 \mathrm{PBS}$ ) solution. As shown in Figure $5 \mathrm{c}, \mathrm{d}$, the catalytic performance of $\left(\mathrm{NH}_{4}\right) \mathrm{Fe}_{3}\left(\mathrm{SO}_{4}\right)_{2}(\mathrm{OH})_{6}$ in the acidic and neutral solution is better than the other three materials. However, the OER performance of $\left(\mathrm{NH}_{4}\right) \mathrm{Fe}_{3}\left(\mathrm{SO}_{4}\right)_{2}(\mathrm{OH})_{6}$ in the acidic and neutral condition is far inferior to that in the alkaline condition. Therefore, we will take alkaline conditions as an example to focus on the $\left(\mathrm{NH}_{4}\right) \mathrm{Fe}_{3}\left(\mathrm{SO}_{4}\right)_{2}(\mathrm{OH})_{6}$ catalyst.

The electrochemical double-layer capacitance $\left(\mathrm{C}_{\mathrm{dl}}\right)$ approach was applied to estimate the electrocatalytic active surface area (ECSA) from cyclic voltammetry curves at various scan rates over a small potential range. The $\left(\mathrm{NH}_{4}\right) \mathrm{Fe}_{3}\left(\mathrm{SO}_{4}\right)_{2}(\mathrm{OH})_{6}$ electrode possesses the largest $\mathrm{C}_{\mathrm{dl}}$ of $15.49 \mathrm{mF} \mathrm{cm}{ }^{-2}$ compared to those of $\mathrm{KFe}_{3}\left(\mathrm{SO}_{4}\right)_{2}(\mathrm{OH})_{6}(6.69 \mathrm{mF}$ $\left.\mathrm{cm}^{-2}\right), \mathrm{NaFe}_{3}\left(\mathrm{SO}_{4}\right)_{2}(\mathrm{OH})_{6}\left(13.56 \mathrm{mF} \mathrm{cm}{ }^{-2}\right)$, and $\left(\mathrm{H}_{3} \mathrm{O}\right) \mathrm{Fe}_{3}\left(\mathrm{SO}_{4}\right)_{2}(\mathrm{OH})_{6}\left(4.28 \mathrm{mF} \mathrm{cm}^{-2}\right)$ 
(Figures 5 and 6), showing indeed that a larger ECSA of $\left(\mathrm{NH}_{4}\right) \mathrm{Fe}_{3}\left(\mathrm{SO}_{4}\right)_{2}(\mathrm{OH})_{6}$ allows for more exposed active sites to promote OER performance.
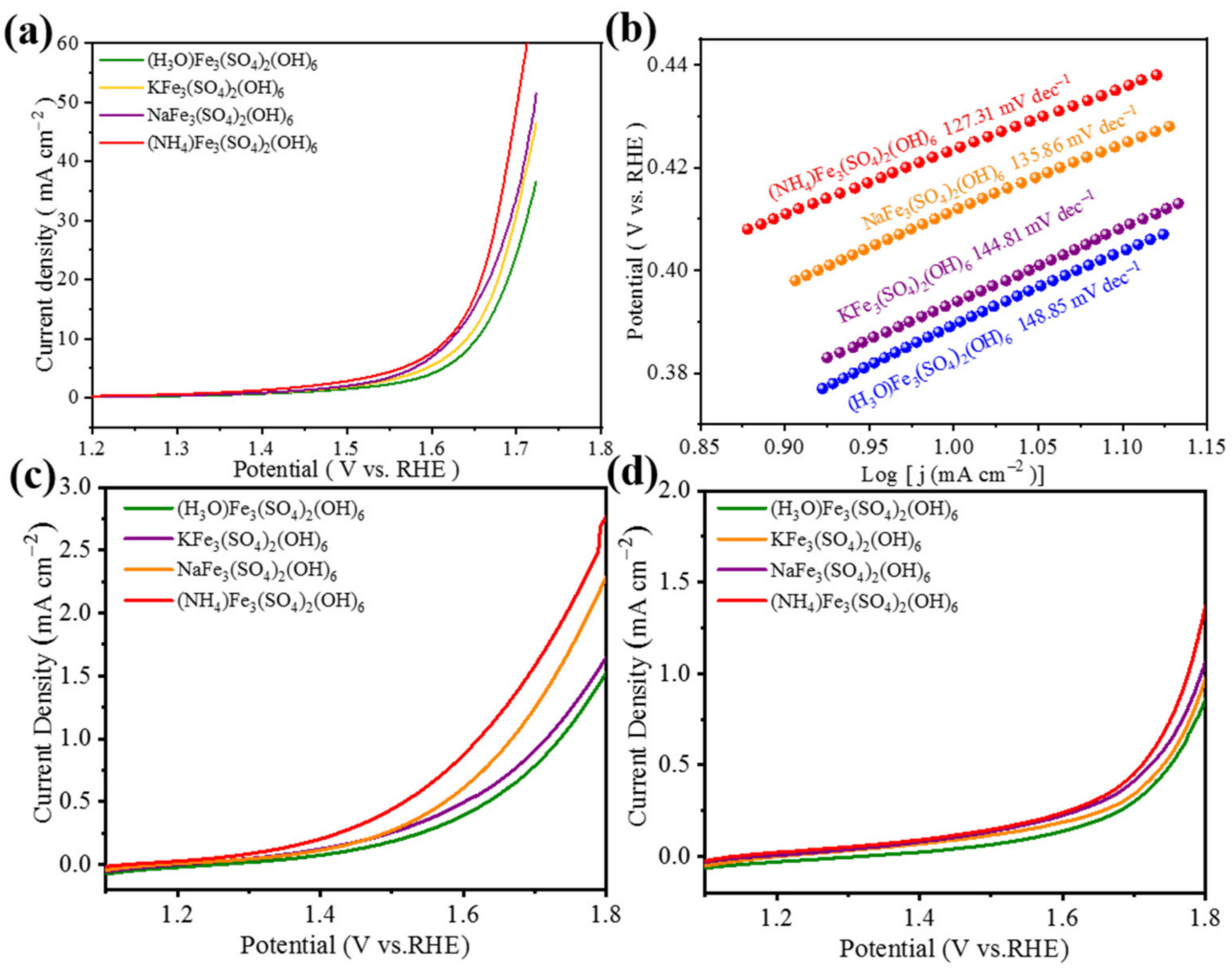

Figure 4. Polarization curves for jarosite to conductive carbon black ratio of 1:1, (a) $1 \mathrm{M} \mathrm{KOH}$ $(\mathrm{pH}=14)$ polarization curves, $(\mathbf{b})$ Tafel plots derived from the $\mathrm{Ph}=14$ polarization curves, (c) $0.05 \mathrm{M}$ $\mathrm{H}_{2} \mathrm{SO}_{4}(\mathrm{pH}=1)$ polarization curves, (d) $1 \mathrm{M}$ PBS $(\mathrm{pH}=7)$ polarization curves.
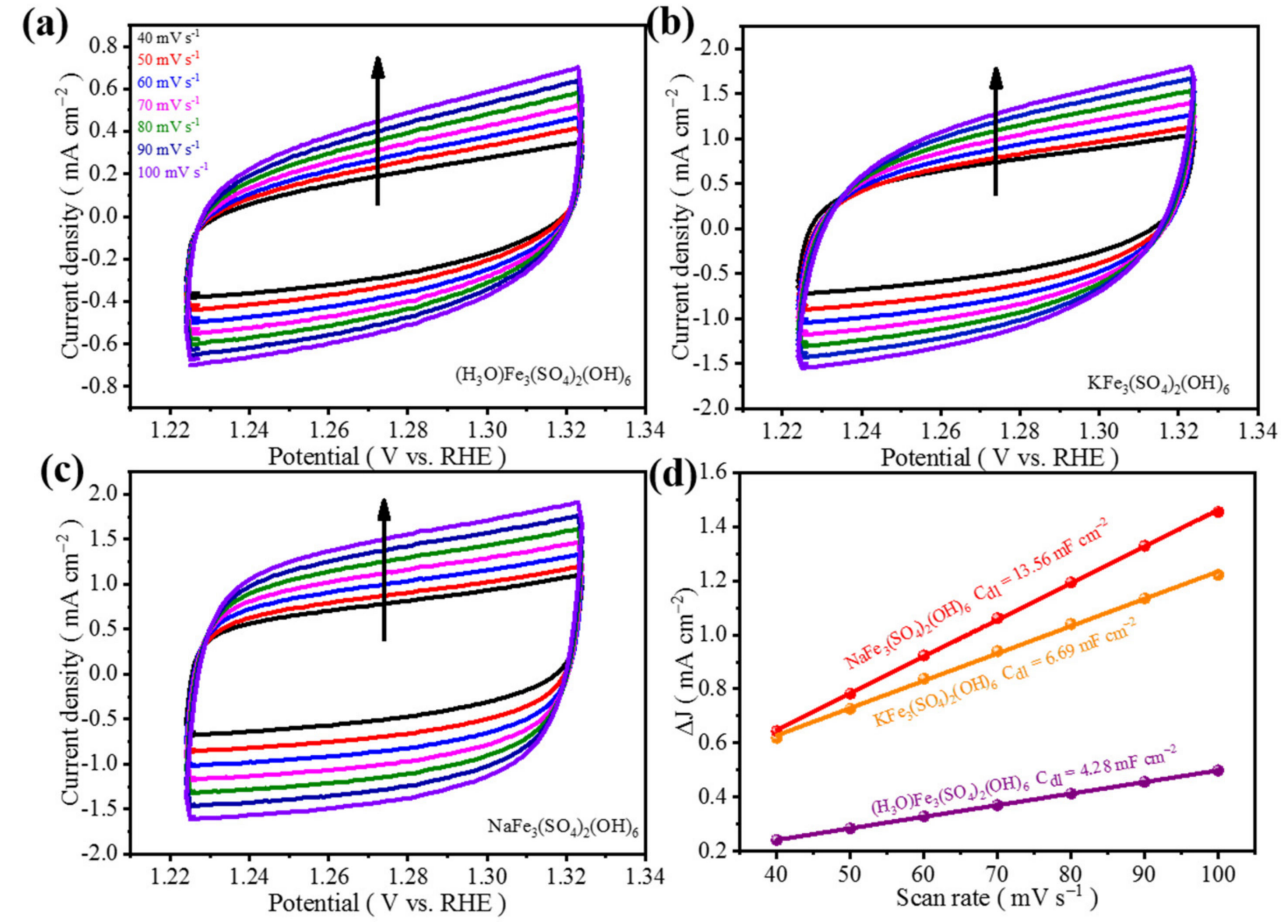

Figure 5. $\mathrm{CV}$ curves of $(\mathbf{a}-\mathbf{c})\left(\mathrm{H}_{3} \mathrm{O}\right) \mathrm{Fe}_{3}\left(\mathrm{SO}_{4}\right)_{2}(\mathrm{OH})_{6}, \mathrm{KFe}_{3}\left(\mathrm{SO}_{4}\right)_{2}(\mathrm{OH})_{6}$, and $\mathrm{NaFe}_{3}\left(\mathrm{SO}_{4}\right)_{2}(\mathrm{OH})_{6}$ at different scan rates, (d) $\mathrm{C}_{\mathrm{dl}}$ diagram of $\left(\mathrm{H}_{3} \mathrm{O}\right) \mathrm{Fe}_{3}\left(\mathrm{SO}_{4}\right)_{2}(\mathrm{OH})_{6}, \mathrm{KFe}_{3}\left(\mathrm{SO}_{4}\right)_{2}(\mathrm{OH})_{6}$, and $\mathrm{NaFe}_{3}\left(\mathrm{SO}_{4}\right)_{2}(\mathrm{OH})_{6}$. 

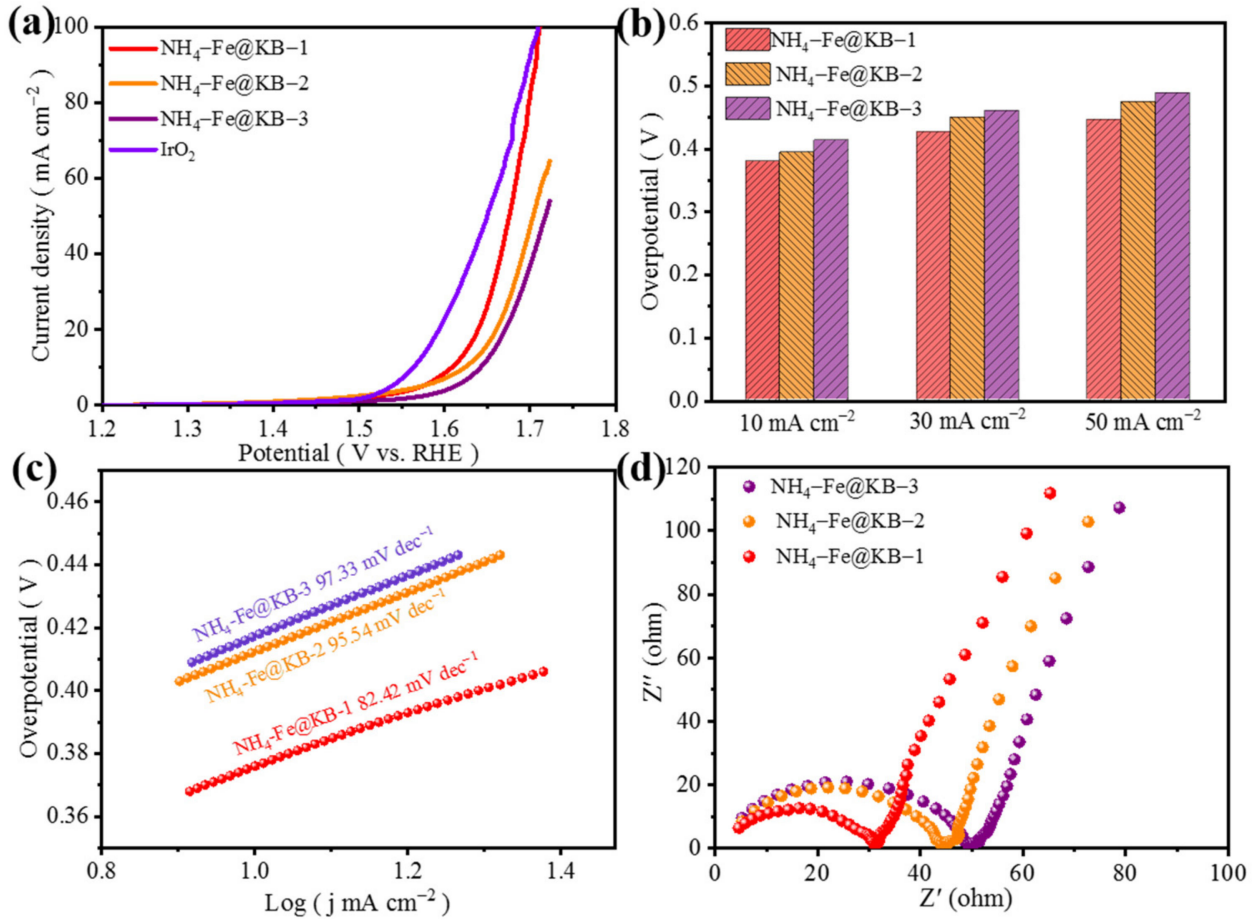

Figure 6. (a) $\mathrm{NH}_{4}-\mathrm{Fe}_{3} @ \mathrm{~KB}-1, \mathrm{NH}_{4}-\mathrm{Fe}_{3} @ \mathrm{~KB}-2, \mathrm{NH}_{4}-\mathrm{Fe}_{3} @ \mathrm{~KB}-3$ and $\mathrm{IrO}_{2}$ polarization curves; (b) $\mathrm{NH}_{4}$ $\mathrm{Fe}_{3} @ \mathrm{~KB}-1, \mathrm{NH}_{4}-\mathrm{Fe}_{3} @ \mathrm{~KB}-2, \mathrm{NH}_{4}-\mathrm{Fe}_{3} @ \mathrm{~KB}-3$ at overpotentials reaching current densities of 10, 50, and $100 \mathrm{~mA} \mathrm{~cm}^{-2}$; (c,d) the Tafel slope and EIS diagram of $\mathrm{NH}_{4}-\mathrm{Fe}_{3} @ \mathrm{~KB}-1, \mathrm{NH}_{4}-\mathrm{Fe}_{3} @ \mathrm{~KB}-2, \mathrm{NH}_{4}-\mathrm{Fe}_{3} @ \mathrm{~KB}-3$.

Different ratios of catalyst powder and conductive carbon black may affect the results. The different weight ratios of $\left(\mathrm{NH}_{4}\right) \mathrm{Fe}_{3}\left(\mathrm{SO}_{4}\right)_{2}(\mathrm{OH})_{6}$ and conductive carbon black (2:1, 1:1, 1:2) are prepared and the total mass of $10 \mathrm{mg}$ is guaranteed. The samples are referred to as $\mathrm{NH}_{4}-\mathrm{Fe}_{3} @ \mathrm{~KB}-1, \mathrm{NH}_{4}-\mathrm{Fe} @ \mathrm{~KB}-2, \mathrm{NH}_{4}-\mathrm{Fe} @ \mathrm{~KB}-3$ and $\mathrm{IrO}_{2}$. The OER polarization curve test was performed on them in $1 \mathrm{M} \mathrm{KOH}$ electrolyte saturated with oxygen, and the test results are shown in Figure 6a. Additionally, $\mathrm{NH}_{4}-\mathrm{Fe}_{3} @ \mathrm{~KB}-1$ has better OER catalytic performance. When the current density is $10 \mathrm{~mA} \mathrm{~cm}{ }^{-2}$, the overpotential of $\mathrm{NH}_{4}-\mathrm{Fe}_{3} @ \mathrm{~KB}-1$ is $379 \mathrm{mV}$, and it is $15 \mathrm{mV}$ and $34 \mathrm{mV}$ lower than $\mathrm{NH}_{4}-\mathrm{Fe}_{3} @ \mathrm{~KB}-2$ and $\mathrm{NH}_{4}-\mathrm{Fe}_{3} @ \mathrm{~KB}-3$, respectively. Furthermore, $\left(\mathrm{NH}_{4}\right) \mathrm{Fe}_{3}\left(\mathrm{SO}_{4}\right)_{2}(\mathrm{OH})_{6}$ and $\mathrm{IrO}_{2}$ have the same overpotential when the current density is $100 \mathrm{~mA} \mathrm{~cm}^{-2}$. When the current density is $30 \mathrm{~mA} \mathrm{~cm}^{-2}$ and $50 \mathrm{~mA} \mathrm{~cm}^{-2}$, the overpotential of $\mathrm{NH}_{4}-\mathrm{Fe}_{3} @ \mathrm{~KB}-1$ is still the lowest (Figure $6 \mathrm{~b}$ ). $\mathrm{NH}_{4}-\mathrm{Fe}_{3} @ \mathrm{~KB}-1$ has a higher current density with the same measurement conditions.

To get insight into the OER kinetics, the Tafel slope values were calculated from the steadystate OER polarization curves. As shown in Figure 6c, $\mathrm{NH}_{4}-\mathrm{Fe}_{3} @ \mathrm{~KB}-1\left(82.42 \mathrm{mV} \mathrm{dec}{ }^{-1}\right)$ has the smallest Tafel slope. Figure $6 \mathrm{~d}$ is the AC impedance (EIS) test results of $\mathrm{NH}_{4}-\mathrm{Fe}_{3} @ \mathrm{~KB}-1$, $\mathrm{NH}_{4}-\mathrm{Fe}_{3} @ \mathrm{~KB}-2$ and $\mathrm{NH}_{4}-\mathrm{Fe}_{3} @ \mathrm{~KB}-3$. The charge transfer resistance of $\mathrm{NH}_{4}-\mathrm{Fe}_{3} @ \mathrm{~KB}-1$ is significantly smaller than that of $\mathrm{NH}_{4}-\mathrm{Fe}_{3} @ \mathrm{~KB}-2$ and $\mathrm{NH}_{4}-\mathrm{Fe}_{3} @ \mathrm{~KB}-3$, which suggests the catalytic interface and the electrolyte have a faster charge transfer rate.

The slope was calculated to get the $\mathrm{C}_{\mathrm{dl}}$ value and the test result is shown in Figure 7. $\mathrm{NH}_{4}-\mathrm{Fe}_{3} @ \mathrm{~KB}-1$ has the largest $\mathrm{C}_{\mathrm{dl}}$ value of $26.17 \mathrm{mF} \mathrm{cm}^{-2}$, indicating that the ECSA of $\mathrm{NH}_{4}$ $\mathrm{Fe}_{3} @ \mathrm{~KB}-1$ is large. This is allowing more active sites to be exposed and promotes the catalytic process of OER. This also explains the good OER catalytic performance of $\mathrm{NH}_{4}-\mathrm{Fe}_{3} @ \mathrm{~KB}-1$.

Additionally, durability was another significant parameter of the catalyst for OER. Through the i- $t$ test, the stability of $\mathrm{NH}_{4}-\mathrm{Fe}_{3} @ \mathrm{~KB}-1$ was evaluated, and the test was carried out for $48 \mathrm{~h}$ at a constant voltage of $0.68 \mathrm{~V}$ (vs. $\mathrm{Hg} / \mathrm{HgO}$ ) with a current density equal to $10 \mathrm{~mA} \mathrm{~cm}{ }^{-2}$. The test results are shown in Figure 8a. With the increase in test time, the current density of $\mathrm{NH}_{4}-\mathrm{Fe}_{3} @ \mathrm{~KB}-1$ increases slightly around $10 \mathrm{~mA} \mathrm{~cm}{ }^{-2}$, which may be caused by the burst of oxygen bubbles generated during the test. Overall, $\mathrm{NH}_{4}-\mathrm{Fe}_{3} @ \mathrm{~KB}-1$ still shows good stability. The structure and composition of $\left(\mathrm{NH}_{4}\right) \mathrm{Fe}_{3}\left(\mathrm{SO}_{4}\right)_{2}(\mathrm{OH})_{6}$ after 
the stability test was also studied in detail, with the SEM image of $\left(\mathrm{NH}_{4}\right) \mathrm{Fe}_{3}\left(\mathrm{SO}_{4}\right)_{2}(\mathrm{OH})_{6}$ (Figure $8 \mathrm{~b}$ ) after stability test displaying a newly formed rice-like structure, indicating that the $\left(\mathrm{NH}_{4}\right) \mathrm{Fe}_{3}\left(\mathrm{SO}_{4}\right)_{2}(\mathrm{OH})_{6}$ catalyst may have undergone surface reconstruction during electrolysis. In addition, the XRD pattern (Figure $8 \mathrm{c}$ ) of the $\left(\mathrm{NH}_{4}\right) \mathrm{Fe}_{3}\left(\mathrm{SO}_{4}\right)_{2}(\mathrm{OH})_{6}$ catalyst showed an amorphous feature after OER. As with many reported works [29,30], the catalyst undergoes a surface reconstruction accompanied by the appearance of an amorphous structure (e.g., oxyhydroxide species) during the OER process, and the observed amorphous feature was further analyzed by Raman spectroscopy. As shown in Figure 8d, the four Raman bands at 215, 275, 390 and $599 \mathrm{~cm}^{-1}$ represent the phase of FeOOH, which is wellmatched with the literature reports [31-33]. Therefore, it might be reasonable to conclude that $\left(\mathrm{NH}_{4}\right) \mathrm{Fe}_{3}\left(\mathrm{SO}_{4}\right)_{2}(\mathrm{OH})_{6}$ was transformed into amorphous FeOOH during the OER process.
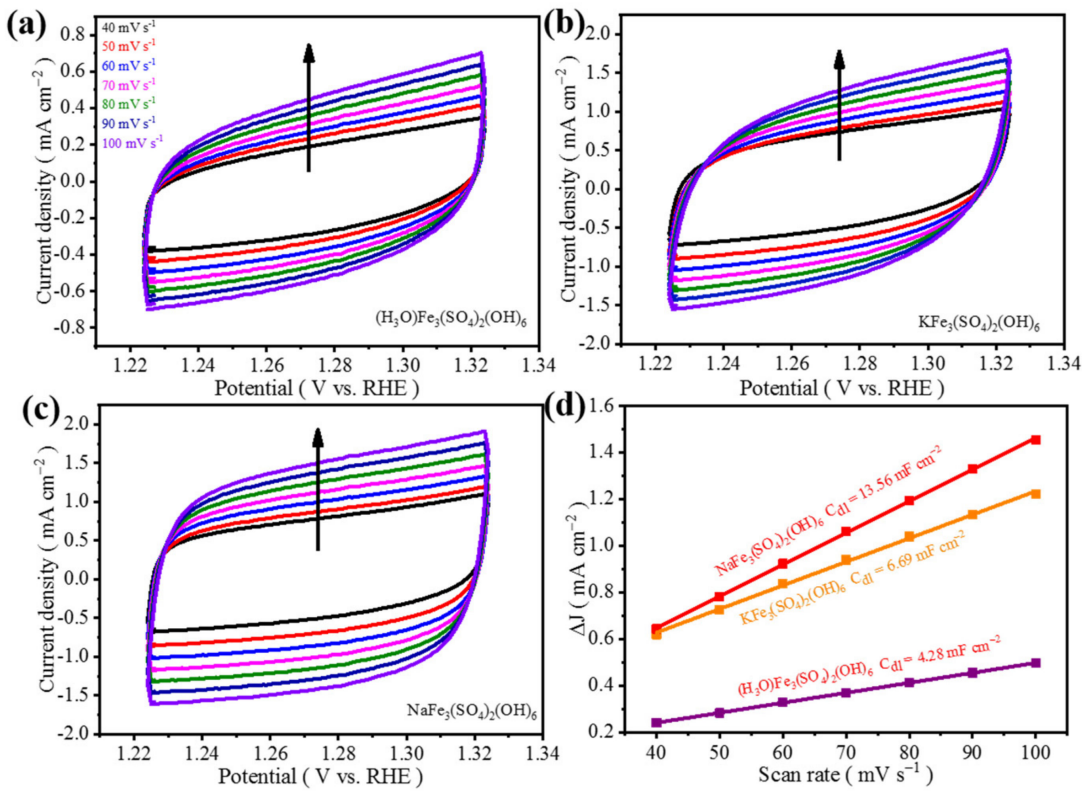

Figure 7. CV curves of (a) $\mathrm{NH}_{4}-\mathrm{Fe}_{3} @ \mathrm{~KB}-1$, (b) $\mathrm{NH}_{4}-\mathrm{Fe}_{3} @ \mathrm{~KB}-2$, and (c) $\mathrm{NH}_{4}-\mathrm{Fe}_{3} @ \mathrm{~KB}-3$ at different scan rates; (d) $\mathrm{C}_{\mathrm{dl}}$ diagram of $\mathrm{NH}_{4}-\mathrm{Fe}_{3} @ \mathrm{~KB}-1, \mathrm{NH}_{4}-\mathrm{Fe}_{3} @ \mathrm{~KB}-2$, and $\mathrm{NH}_{4}-\mathrm{Fe}_{3} @ \mathrm{~KB}-3$.

(a)

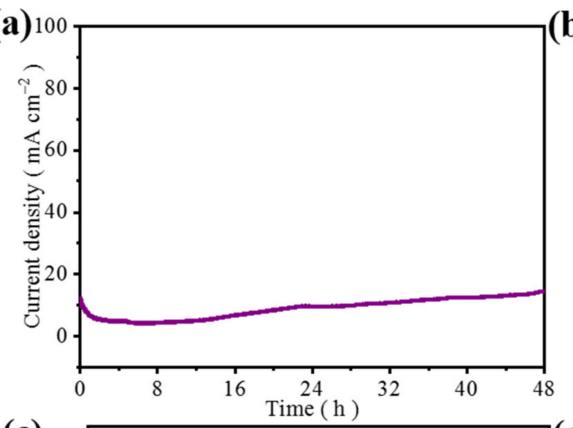

(c)

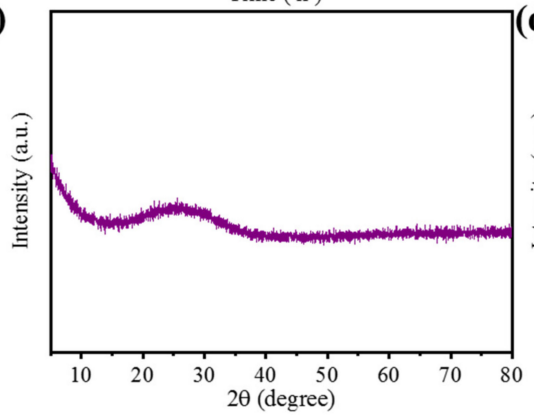

(b)
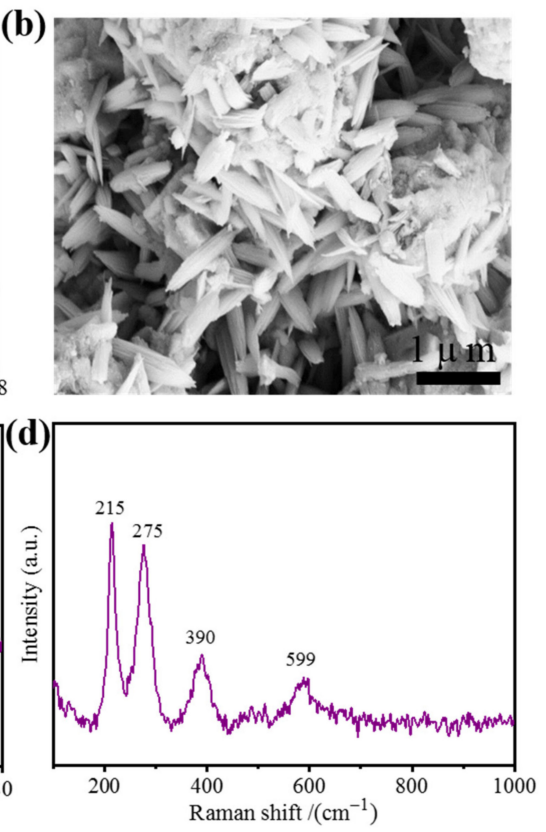

Figure 8. (a) The chronoamperometric curve for $\mathrm{NH}_{4}-\mathrm{Fe}_{3} @ \mathrm{~KB}-1$, (b) SEM after stability test, (c) XRD after stability test, (d) Raman after stability test. 


\section{Conclusions}

In this work, a simple hydrothermal method was used to successfully prepare the jarosite. Furthermore, $\left(\mathrm{NH}_{4}\right) \mathrm{Fe}_{3}\left(\mathrm{SO}_{4}\right)_{2}(\mathrm{OH})_{6}$ shows the best catalytic performance. The OER catalytic performance of $\left(\mathrm{NH}_{4}\right) \mathrm{Fe}_{3}\left(\mathrm{SO}_{4}\right)_{2}(\mathrm{OH})_{6}$ and conductive carbon black with different weight ratios were further explored. The OER catalytic performance is best when the weight ratio of $\left(\mathrm{NH}_{4}\right) \mathrm{Fe}_{3}\left(\mathrm{SO}_{4}\right)_{2}(\mathrm{OH})_{6}$ to conductive carbon black is 2:1. Additionally, $\mathrm{NH}_{4}-\mathrm{Fe}_{3} @ \mathrm{~KB}-1$ has a lower starting potential of $1.42 \mathrm{~V}$ (vs. RHE) and Tafel slope $\left(82.42 \mathrm{mV} \mathrm{dec}^{-1}\right)$. It also showed a small charge transfer resistance and a large $\mathrm{C}_{\mathrm{dl}}$ $\left(26.17 \mathrm{mF} \mathrm{cm}^{-2}\right)$. The raw materials for preparing the synthetic are easily obtained and are low in price. Experimental results show that jarosite has a broad development space and further research is needed to improve its OER performance.

Author Contributions: Conceptualization, J.C., S.L. and Y.L.; methodology, J.C. and S.L.; software, J.C. and S.L.; validation, Z.Q., Z.L. and D.W.; formal analysis, J.C. and S.L.; investigation, J.C. and S.L.; resources, Y.L.; data curation, S.L.; writing-original draft preparation, J.C. and S.L.; writing-review and editing, J.C.; visualization, J.S. and Y.L.; supervision, J.S. and Y.L.; project administration, Y.L. All authors have read and agreed to the published version of the manuscript.

Funding: This research received no external funding.

Institutional Review Board Statement: Not applicable.

Informed Consent Statement: Not applicable.

Data Availability Statement: The data used to support the findings of this study are available from the corresponding author upon request.

Acknowledgments: The authors are grateful for the Key Laboratory of New Processing Technology for Nonferrous Metals and Materials, Ministry of Education, Guilin University of Technology.

Conflicts of Interest: The authors declare no conflict of interest.

\section{References}

1. Zhao, D.D.; Zhang, N.; Bu, L.Z.; Shao, Q.; Huang, X.Q. The latest development of non-noble metal electrocatalytic oxygen evolution catalysts. Electrochemistry 2018, 24, 455-465.

2. Guo, Y.X.; Shang, C.S.; Li, J.; Wang, E.K. Research progress in electrocatalytic hydrogen evolution, oxygen evolution, and oxygen reduction. Sci. China Chem. 2018, 48, 926-940.

3. Shao, Q.; Yang, J.; Huang, X. The Design of Water Oxidation Electrocatalysts from Nanoscale Metal-Organic Frameworks. Chem. Eur. J. 2018, 24, 15143-15155. [CrossRef] [PubMed]

4. Goodenough, J.B.; Park, K.S. The Li-ion rechargeable battery: A perspective. J. Am. Chem. Soc. 2013, 135, 1167-1176. [CrossRef] [PubMed]

5. Wang, H.; Wang, W.; Xu, Y.Y.; Dong, S.; Xiao, J.; Wang, F.; Liu, H.; Xia, B.Y. Hollow nitrogen-doped carbon spheres with $\mathrm{Fe}_{3} \mathrm{O}_{4}$ nanoparticles encapsulated as a highly active oxygen-reduction catalyst. ACS Appl. Mater. Interfaces 2017, 9, 10610-10617. [CrossRef] [PubMed]

6. Long, X.; Xiao, S.; Wang, Z.; Zheng, X.; Yang, S. Co intake mediated formation of ultrathin nanosheets of transition metal LDH-an advanced electrocatalyst for oxygen evolution reaction. Chem. Commun. 2015, 51, 1120-1123. [CrossRef]

7. Luo, Y.; Wu, Y.; Wu, D.; Huang, C.; Xiao, D.; Chen, H.; Zheng, S.; Chu, P.K. NiFe-Layered Double Hydroxide synchronously activated by heterojunctions and Vacancies for the Oxygen Evolution Reaction. Appl. Mater. Interfaces 2020, 12, 42850-42858. [CrossRef] [PubMed]

8. Zhang, X.; Zhang, X.; Xu, H.; Wu, Z.; Wang, H.; Liang, Y. Iron-Doped cobalt monophosphide Nanosheet/Carbon nanotube hybrids as active and stable electrocatalysts for water splitting. Adv. Funct. Mater. 2017, 27, 1606635. [CrossRef]

9. Xu, K.; Chen, P.; Li, X.; Tong, Y.; Ding, H.; Wu, X.; Chu, W.; Peng, Z.; Wu, C.; Xie, Y. Metallic Nickel Nitride nanosheets realizing enhanced electrochemical water oxidation. J. Am. Chem. Soc. 2015, 137, 4119-4125. [CrossRef] [PubMed]

10. Huo, J.; Wang, Y.; Yan, L.; Xue, Y.; Li, S.; Hu, M.; Jiang, Y.; Zhai, Q.G. In situ semi-transformation from heterometallic MOFs to Fe-Ni $\mathrm{LDH} / \mathrm{MOF}$ hierarchical architectures for boosted oxygen evolution reaction. Nanoscale 2020, 12, 14514. [CrossRef] [PubMed]

11. Lu, X.; Yim, W.L.; Suryanto, B.H.; Zhao, C. Electrocatalytic oxygen evolution at Surface-Oxidized multiwall carbon nanotubes. J. Am. Chem. Soc. 2015, 137, 2901-2907. [CrossRef] [PubMed]

12. Lu, J.; Zhou, W.; Wang, L.; Jia, J.; Ke, Y.; Yang, L.; Zhou, K.; Liu, X.; Tang, Z.; Li, L.; et al. Core-shell nanocomposites based on gold nanoparticle @Zinc-iron- embedded porous carbons derived from metal-organic frameworks as efficient dual catalysts for oxygen reduction and hydrogen evolution reactions. ACS Catal. 2016, 6, 1045-1053. [CrossRef]

13. Li, X.; Hao, X.; Wang, Z.; Abudula, A.; Guan, G. In-situ intercalation of NiFe LDH materials: An effificient approach to improve electrocatalytic activity and stability for water splitting. J. Power Sources 2017, 347, 193-200. [CrossRef] 
14. Smith, R.D.; Sporinova, B.; Fagan, R.D.; Trudel, S.; Berlinguette, C.P. Facile photochemical preparation of amorphous iridium oxide films for water oxidation catalysis. Chem. Mater. 2014, 26, 1654-1659. [CrossRef]

15. Su, L.W.; Zhou, Z.; Shen, P.W. Core-shell Fe@ $\mathrm{Fe}_{3} \mathrm{C} / \mathrm{C}$ Nanocomposites as Anode Materials for Li Ion Batteries. Electrochim. Acta 2013, 87, 180-185. [CrossRef]

16. Boyanov, S.; Bernardi, J.; Gillot, F.; Dupont, L.; Womes, M.; Tarascon, J.M.; Monconduit, L.; Doublet, M.L. FeP: AnotherAttractive Anode for the Li-Ion Battery Enlisting a Reversible Two-Step Insertion/Conversion Process. Chem. Mater. 2006, 18, 3531-3538. [CrossRef]

17. Boyanov, S.; Womes, M.; Monconduit, L.; Zitoun, D. Mossbauer Spectroscopy and Magnetic Measurements As Comple-mentary Techniques for the Phase Analysis of FeP Electrodes Cycling in Li-Ion Batteries. Chem. Mater. 2009, 21, 3684-3692. [CrossRef]

18. Ding, X.; Yin, S.; An, K.; Luo, L.; Shi, N.; Qiang, Y.; Pasupathi, S.; Pollet, B.G.; Shen, P.K. FeN stabilized FeN@Pt core-shell nanostructures for oxygen reduction reaction. J. Mater. Chem. A 2015, 3, 4462-4469. [CrossRef]

19. Cai, Z.; Zhou, D.; Wang, M.; Bak, S.M.; Wu, Y.; Wu, Z.; Tian, Y.; Xiong, X.; Li, Y.; Liu, W.; et al. Introducing $\mathrm{Fe}^{2+}$ into nickel-iron layered double hydroxide: Local structure modulated water oxidation activity. Angew. Chem.-Int. Ed. 2018, 130, 9536-9540. [CrossRef]

20. Basciano, L.C.; Peterson, R.C. The crystal structure of ammoniojarosite, $\left(\mathrm{NH}_{4}\right) \mathrm{Fe}_{3}\left(\mathrm{SO}_{4}\right) \mathrm{W}(\mathrm{OH})_{6}$ and the crystal chemistry of the ammoniojarosite-hydronium jarosite solid-solution series. Mineral. Mag. 2007, 71, 427-441. [CrossRef]

21. Frost, R.; Wills, R.A.; Kloprogge, J.; Martens, W. Thermal decomposition of ammonium jarosite $\left(\mathrm{NH}_{4}\right) \mathrm{Fe}_{3}\left(\mathrm{SO}_{4}\right)_{2}(\mathrm{OH})_{6}$. J. Therm. Anal. Calorim. 2006, 84, 489-496. [CrossRef]

22. Li, H.J.; Yang, H.Y.; Chen, G.B. Catalytic performance of biological method seeds on jarosite process. Trans. Nonferrous Met. Soc. China 2016, 26, 557-564. [CrossRef]

23. Liu, F.; Shi, J.; Duan, J.; Zhou, L.; Xu, J.; Hao, X.; Fan, W. Significance of jarosite dissolution from the biooxidized pyrite surface on further biooxidation of pyrite. Hydrometallurgy 2018, 176, 33-41. [CrossRef]

24. Xu, W.; Xie, Z.; Cui, X.; Zhao, K.; Zhang, L.; Mai, L.; Wang, Y. Direct growth of an economic green energy storage material: A monocrystalline jarosite- $\mathrm{KFe}_{3}\left(\mathrm{SO}_{4}\right)_{2}(\mathrm{OH})_{6}$-nanoplates@rGO hybrid as a superior lithium-ion battery cathode. J. Mater. Chem. A 2016, 4, 3735-3742. [CrossRef]

25. Wu, N.; Tian, W.; Shen, J.; Qiao, X.; Sun, T.; Wu, H.; Zhao, J.; Liu, X.; Zhang, Y. Facile fabrication of a jarosite ultrathin $\mathrm{KFe}_{3}\left(\mathrm{SO}_{4}\right)_{2}(\mathrm{OH})_{6} @ \mathrm{rGO}$ nanosheet hybrid composite with pseudocapacitive contribution as a robust anode for lithiumion batteries. Inorg. Chem. Front. 2019, 6, 192-198. [CrossRef]

26. Wang, X.L.; Dong, L.Z.; Qiao, M.; Tang, Y.J.; Liu, J.; Li, Y.; Li, S.L.; Su, J.X.; Lan, Y.Q. Exploring the performance improvement of the oxygen evolution reaction in a stable bimetal-organic framework system. Angew. Chem.-Int. Ed. 2018, 57, 1-6.

27. Gao, K.; Jiang, M.; Guo, C.; Zeng, Y.; Fan, C.; Zhang, J.; Reinfelder, J.R.; Huang, W.; Lu, G.; Dang, Z. Reductive dissolution of jarosite by a sulfate reducing bacterial community: Secondary mineralization and microflflora development. Sci. Total Environ. 2019, 690, 1100-1109. [CrossRef] [PubMed]

28. Liu, C.; Ling, Z.; Zhang, J.; Bi, X.; Xin, Y. Laboratory Raman and VNIR spectroscopic studies of jarosite and other secondary mineral mixtures relevant to Mars. J. Raman Spectrosc. 2020, 51, 1575-1588. [CrossRef]

29. Duan, Y.; Lee, J.Y.; Xi, S.; Sun, Y.; Ge, J.; Ong, S.J.H.; Chen, Y.; Dou, S.; Meng, F.; Diao, C.; et al. Anodic Oxidation Enabled Cation Leaching for Promoting Surface Reconstruction in Water Oxidation. Angew. Chem.-Int. Ed. 2021, 133, 7418-7425. [CrossRef]

30. Liu, X.; Meng, J.; Ni, K.; Guo, R.; Xia, F.; Xie, J.; Li, X.; Wen, B.; Wu, P.; Li, M.; et al. Complete Reconstruction of Hydrate Pre-Catalysts for Ultrastable Water Electrolysis in Industrial-Concentration Alkali Media. Cell Rep. Phys. Sci. 2020, 1, 100241. [CrossRef]

31. Hu, J.; Li, S.; Chu, J.; Niu, S.; Wang, J.; Du, Y.; Li, Z.; Han, X.; Xu, P. Understanding the Phase-Induced Electrocatalytic Oxygen Evolution Reaction Activity on FeOOH Nanostructures. ACS Catal. 2019, 9, 10705-10711. [CrossRef]

32. Xiao, T.; Yang, C.; Lu, Y.; Zeng, F. One-pot hydrothermal synthesis of rod-like FeOOH/reduced graphene oxide composites for supercapacitor. Journal of Materials Science. Mater. Electron. 2014, 25, 3364-3374. [CrossRef]

33. Ohtsuka, T.; Tanaka, S. Monitoring the development of rust layers on weathering steel using in situ Raman spectroscopy under wet-and-dry cyclic conditions. J. Solid State Electrochem. 2015, 19, 3559-3566. [CrossRef] 